\title{
MODELLING LAND-USE REGULATION CONFLICTS WITH 3D COMPONENTS TO SUPPORT ISSUING A BUILDING PERMIT
}

\author{
S. Emamgholian ${ }^{1 *}$ J. Pouliot ${ }^{1}$, D. Shojaei ${ }^{2}$ \\ ${ }^{1}$ Dept. of Geomatics, Université Laval, Québec, Canada - saeid.emamgholian.1@ulaval.ca; jacynthe.pouliot@scg.ulaval.ca \\ ${ }^{2}$ Centre for SDIs and Land Administration, Department of Infrastructure Engineering, The University of Melbourne, Parkville, \\ Victoria, Australia - shojaeid@unimelb.edu.au
}

Commission VI, WG VI/4

KEY WORDS: Land Information System, Land-Use Regulations, Conflict, Building Permit, 3D City Model, Data Modelling

\begin{abstract}
:
Cities are facing important challenges due to population growth and massive development of high-rises and complex structures above and below the ground surface. In that respect, having an efficient land-use regulation framework in force is necessary for cities. In investigating current practices for processing spatial data when issuing building permits, in many cases, the planned building is drawn on 2D plans with cross-sections to represent their 3D dimensions. In complex multilevel developments, this method has significant shortcomings like the requirement of managing numerous plans and sections, and uncertainty in decisions more specifically when checking land-use regulations comprising 3D components (e.g. height limits, overhanging objects, solar rights). In order to support issuing a building permit and moving towards the establishment of 3D smart cities, this paper presents an inventory for land-use regulations with 3D components and functional classification of their possible conflicts. Two functional classifications of possible conflicts in a building permit process from two points of view (i.e. data integration process, and magnitude of land-use regulation conflicts) are proposed. These results are placed in the context of having 3D city models that integrate landuse regulation information.
\end{abstract}

\section{INTRODUCTION}

\subsection{Context}

Rapid rates of urbanization and the increasing development of buildings and high-rises bring new challenges for city authorities, including the need to manage heterogeneous and possibly conflicting multilevel land-use regulations. As an example, the experts who issue building permits in a municipality need to verify if new proposed constructions respect the regulations for building height, setbacks (i.e. side street, front street, side, and rear setbacks), daylight, solar access, shadowing, overlooking, etc. This process includes checking the proposed application against planning and building regulations (Benner et al., 2010; Noardo et al., 2020; Olsson et al., 2018; Van Berlo et al., 2013). In such situation, they need to integrate various information to check the consistency of permit application with land-use regulations from various points of view such as geometry (e.g. specification of the zones where buildings are allowed to be built) and semantic (e.g. specification of maximum height or minimum setback distance) (Stadler and Kolbe, 2007). Finally, they need to identify possible conflicts to determine if the building permit should be approved or not.

The majority of land-use regulations are defined based on the planning activities, zoning codes, permit requirements and conditions, and subdivision controls of cities (Durham $\mathrm{Jr}$ and Scharffs, 2019; Forester, 1987; Selmi et al., 2017). Land-use regulation, on one hand, restricts illegal activities, which may not be obvious to residents, and on the other hand, causes extra expenses (Cann, 2018; Kochan, 2014). It is often integrated into a legal framework to control land usage and its main goal is to mediate between social space and physical space in which developers (including owners, investors, builders, etc.) often dispute about spatial conflicts of these regulations with local residents and municipalities (Arnold, 2006; Mayer and Somerville, 2000; Selmi et al., 2017). According to Gresch and Smith (1985) "spatial conflicts are overt public disagreements about some actual or proposed use of land or property development".

\subsection{Problem Statement}

\subsubsection{Thinking in 3D, working in 2D}

Currently, land-use regulations are interpreted in a planning system which is mainly based on 2D maps (Benner et al., 2010; Van Berlo et al., 2013). In addition, proposed buildings are represented using two-dimensional (2D) plans, cross-sections, textual descriptions, and attributes of the building elements (e.g. height) (Benner et al., 2010; Noardo et al., 2020; Olsson et al., 2018; Van Berlo et al., 2013). In addition, land-use regulations are mainly textual documents, open to interpretation, that some of them might be linked to 2D planning maps.

While the land-use regulations in a region or state, theoretically, may be defined in a 3D space (e.g. maximum allowed height, or overlooking regulations), the spatial representations that support their graphical interpretation by decision-makers (e.g. land lawyers, urban planners, and land surveyors) are mainly 2D based (Olsson et al., 2018; Van Berlo et al., 2013). Accordingly, in situations where 3D components (e.g. height, depth, and volume of building elements or 3D land-use regulations) are involved, the use of $2 \mathrm{D}$ representation may result in challenges for decision-makers (e.g. in checking

\footnotetext{
Corresponding author
} 
overshadowing regulation), and alternatively cause erroneous building permits. For example, Grimmer (2007) reviews a real case where a building was almost built with a higher allowable height according to an erroneously granted permit. In addition, due to the complexity of multi-level developments, numerous plans and sections are required and these are difficult to manually check, and finding land-use regulation conflicts can be very difficult.

\subsubsection{D City modelling and land-use regulations}

3D city models are emerging solutions in the administration of cities that allow integrating various geospatial information such as CityGML models, 3D building models (BIM and GeoBIM), and models of transportation systems into one system through 3D geo-virtual environments (Biljecki et al., 2015; Döllner et al., 2006b, 2006a; Kolbe, 2009; Neuville et al., 2018; Noardo et al., 2019). By considering this characteristic, 3D city models with the capability of 3D analyses (e.g. shadow and line of sight analyses) become suitable geo-context for exploring land-use regulations that rarely investigated (Döllner et al., 2006a, 2006b; Mohammadi, 2008).

Although the third dimension will solve the drawbacks of $2 \mathrm{D}$ environments for exploring land-use regulations that have 3D components, there is still a challenging problem. Land-use regulations and their potential conflicts are some administrative objects that have not been fully integrated yet into 3D city models. Therefore, effective integration and visualization of land-use regulations and their possible conflicts would be a crucial problem in this domain (e.g. visualizing building height or overlooking regulation as well as their possible conflict).

\subsection{Objectives}

A research project has been recently started in collaboration between Laval University (Centre for Research in Geospatial Data and Intelligence) and the University of Melbourne (Centre for SDIs and Land Administration) to precisely address the problem of detecting the geometric and semantic conflicts among land-use regulations with 3D components by considering intended users and their needs. In this context, the first hypothesis of this work is as follows: The decision-maker needs to have access to pre-organised data that will aggregate original 3D data (i.e. physical objects and land-use regulations) in a form that enables the ranking of conflicts. Consequently, as a preliminary phase of this project, the objective of this paper is to propose:

(1) An inventory of land-use regulations comprising 3D components by considering their semantic aspects.

(2) A functional classification of potential land-use regulation conflicts by considering the conflicts' magnitude in the data processing of a building permit issuance and their impacts on a decision-making process.

In this paper, 3D components refer to any information that is required to inspect the space in $3 \mathrm{D}$. The $3 \mathrm{D}$ space may contain physical objects like building elements that integrate the height, depth, or volume and/or administrative objects like land-use regulations that consider the third dimension like building height regulation.

\subsection{Methodology}

The approach consists in describing, interpreting, and contextualizing the concepts related to $3 \mathrm{D}$ land-use regulations for addressing the problems. First, a comprehensive literature review is conducted (Section 2) and an inventory of land-use regulations comprising $3 \mathrm{D}$ components by considering their semantic aspects is proposed (Section 3.1). Second, potential land-use regulation conflicts are classified on the basis of common descriptive characteristics, and two classifications according to attributes are proposed in the domain of planning permit (Section 3.2).

In order to bring together consistent results and reduce the extent of the investigation, the analysis focus on the building permit process. A building permit process is a valuable case study that involves a variety of land-use regulations for which 3D space is considered. Melbourne city area in Victoria, Australia, is selected as a case study, which helps understand the current practice and existing issues and challenges.

Figure 1 illustrates a number of land-use regulations in a building permit process by using SketchUp 3D warehouse samples.

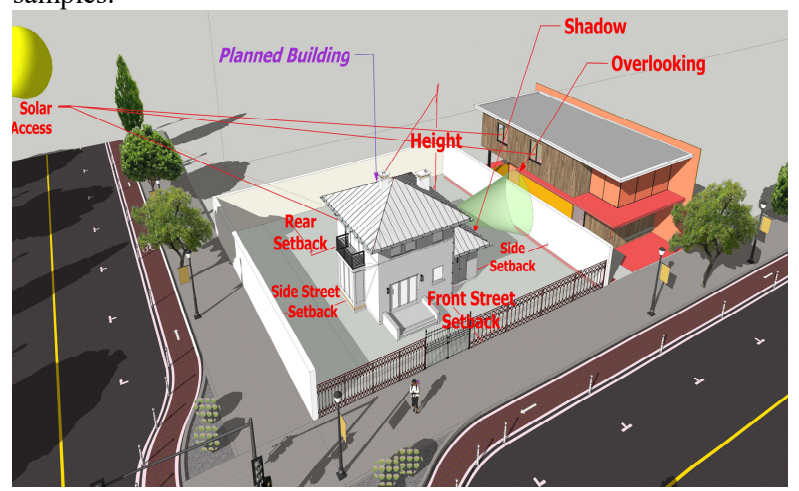

Figure 1. Examples of land-use regulations (in RED colour) for a new proposed (planned) building (left building in the scene)

\section{RELATED STUDIES}

This section reviews related studies in the classification of landuse regulations, classification of possible conflicts in a data integration process as well as previous works related to issuing a building permit.

\subsection{Land-use regulations (in building permit process)}

Typically, land-use regulation behaves as a sub-category of another area of law, such as constitutional law, environmental law, administrative law, or local government law (Arnold, 2006; Salsich and Tryniecki, 1998; Selmi et al., 2017). We can highlight one of its definition in the "Religious Land Use and Institutionalized Persons Act" (RLUIPA) ${ }^{1}$ as: "Zoning or landmarking law, or the application of such a law, that limits or restricts a claimant's use or development of land (including a structure affixed to land), if the claimant has an ownership, leasehold, easement, servitude, or other property interest in the regulated land or a contract or option to acquire such an interest".

Benner et al. (2010) argue that for the building permit process, both geometric and semantic aspects of the data need to be considered. They developed a prototype for checking some regulations such as site occupancy index, floor space ratio, the building height based on the number of storeys, and the roof type, roof shape, and the direction of the ridge. To this purpose, they consider the integration of three kinds of the data including BIM model in IFC format, the city map in CityGML format for

\footnotetext{
1 https://www.justice.gov/crt/religious-land-use-and-institutionalizedpersons-act
} 
existing building surrounding the proposed (planned) construction, and legally binding land-use plan (a German standard) in the XplanGML format in which the objects are represented as $2 \mathrm{D}$ geometries with corresponding attributes. They suggest converting the BIM data to CityGML format and then importing the building data to a city model where the rule checking will be carried out.

Van Berlo et al. (2013) converted the spatial planning map into $3 \mathrm{D}$ building objects by using the maximum allowed building height value given in the regulations. The main focus of their work was on investigating four regulations including the maximum allowed building volume, the maximum percentage of the built area on the site, the maximum allowed noise value on the façade of the buildings, and if protected cultural heritage in the underground is not harmed by the designs. In their work, the rule checking is performed in a BIM environment in which the architects can conduct their own rule checks before submitting the application for the building approval (e.g. using software such as Solibri Model Checker).

Noardo et al. (2020) proposed a GeoBIM workflow (as part of GeoBIM project) for issuing a building permit. The workflow has several steps including reading and using $3 \mathrm{D}$ city model and regulations that can be read by a computer, checking the BIM's validity, semantics and geo-referencing, conversion of BIM to CityGML, analysing the integrated information for checking the picked city regulations, and building permit issuing. In addition, in order to find the common regulation checks amongst the municipalities of participating project partners, they proposed a classification by considering 3D spatial and semantic aspects of these regulations. They classified a number of common land-use regulation checks in European countries as:

- Zoning and dimensions (e.g. maximum height and distances from other buildings);

- Parking availability;

- The impact of building on environment and the impact of environment on building (e.g. overshadowing and air quality)

Olsson et al. (2018) proposed an approach to automate the process of issuing a building permit for three specific regulations including building height, building footprint area, and one visual criterion. Their study is based on the approach of importing the BIM model of new buildings, into a geospatial data environment in which municipalities carry out the legal check of the regulations. In addition, they proposed a classification of the property criteria in Swedish detailed development plans in which they classified the regulations into three main classes by taking to account the main available source of datasets (i.e. BIM, geospatial, and integrated BIM and geospatial data). The three classes are as follows:

- Quantitative regulations, which can be checked automatically (e.g. building heights);

- Qualitative regulations, which are difficult to be checked automatically (e.g. maintenance of specific historical and artistic values); and

- Visual regulations, which can be supported digitally (e.g. configuration of windows).

However, they did not provide any details about the investigated regulations considered in their classification. They just presented the final percentage of regulations in each class.

\subsection{Land-use regulation conflicts}

Despite the extensive research carried out in the last decade in the field of land-use regulation and building permit issuance (Benner et al., 2010; Noardo et al., 2019, 2020; Olsson et al.,
2018; Van Berlo et al., 2013), there is a lack of research with a focus on the investigation about land-use regulation conflicts. For this reason, we decided to extend our literature review to spatio-semantic data conflicts. For instance, Fileto (2001) proposed a classification for conflicts that may arise by having two or more sources of information in the context of relational databases. He investigated these conflicts from two orthogonal aspects as follows.

- Abstraction level

○ Data instance conflicts (e.g. conflicts in units)

- Schema conflicts (e.g. an attribute in one relational schema that is modelled as a relation in another relational schema)

- Data model conflicts (e.g. one database designed according to the relational model while the other is object-oriented)

- Representation and interpretation level

- Syntactic conflicts (i.e. discrepancies in the representation of data)

- Semantic conflicts

Wang and $\mathrm{Hu}(2009)$ described possible conflicts in a spatial data integration process and proposed a number of possible solutions in dealing with these conflicts. They classified the potential conflicts between different spatial data sources into three main classes including:

- System conflicts (when technical aspects such as hardware platforms are different);

- Syntax conflicts (mainly reflected on data models);

- Semantic conflicts (conflicts in the meaning, interpretation or use of the data).

\subsection{Clash detection in Building Information Modelling (BIM)}

3D modelling and BIM, as a part of the literature review, were investigated, and the current approach of clash classification in BIM seemed quite applicable for the assessment of land-use regulation conflicts. For this reason, this section briefly explains the notion of "clash" as a special kind of spatial conflicts (Eastman et al., 2008; Matejka and Sabart, 2018; Mehrbod et al., 2019; Reddy, 2011; Sampaio and Berdeja, 2017; Webster, 1971). Subsequently, section (3.2.2) will explain its correspondence with our proposed classification for land-use regulation conflicts.

Generally, clashes are only applicable to the BIM data and they cannot be applied in a data integration process in which there are other kinds of models such as geospatial data (Eastman et al., 2008; Sampaio and Berdeja, 2017; Webster, 1971). However, it can be considered as a part of a data integration process when several parts of a BIM data are designed by different designers or architects and need to be integrated to create the whole BIM data (that again it is only related to BIM data).

Matejka and Sabart (2018) categorize clashes in four types in the construction process including hard clashes, soft clashes, 4D clashes, and animated clashes (clashes of animated objects). The last two clashes are related to the construction phase and they are out of the scope of this paper.

- Hard clashes refer to only geometrical issues in which two or more building elements intersect or overlap (Reddy, 2011). They can be costly to fix if missed in the design process (e.g. the collision of piping and a beam (column) as shown in Figure 2(a)).

- Soft clashes are the clashes between one entity and another's buffer area, which is set around it (Reddy, 
2011). As an example, Figure 2(b) illustrates a soft clash in which a column is placed right in front of a door.

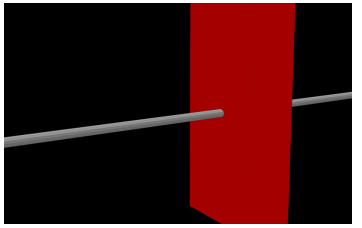

(a)

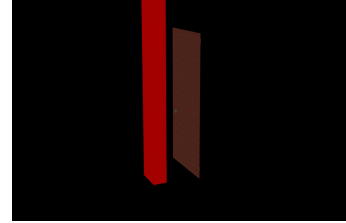

(b)
Figure 2. (a) Hard clash between a pipe and a beam; (b) Soft clash between a door and a beam.

- 4D clashes happen due to low quality in project management and occur during the construction phase (i.e. time is considered). The conflict between the crane and scaffolding during the construction phase is an example of this clash.

- Finally, animated clashes have a dynamic characteristic such as people walking on stairs and through corridors, or components that require manipulation space (e.g. moving a virtual person to inspect the correction of specified measurements through corridors and stairs). These collisions are more similar to soft clashes with the differences in using a dynamic buffer instead of the static one.

Some other researchers have addressed the design conflict that occurs when a building component conflicts with another building component in BIM designs (Akinci et al., 2002; Wu and Chiu, 2010). The conflicts are related to the design phase when a building component conflicts with another. One alternative to identify design conflicts, as well as clashes, is to define some validation rules in order to reduce the potential issues (Ledoux, 2018; Shojaei et al., 2017). For example, in the city of Melbourne, the first phase of cadastral applications is to check the plan by several validation rules to verify its consistency in terms of design conflicts (Shojaei et al., 2017).

\section{MODELLING 3D LAND-USE REGULATIONS}

This section proposes the main contributions of this paper, which are an inventory of land-use regulations comprising 3D components and functional classification of their possible conflicts when representing them in 3D (based on the magnitude of their impacts on issuing building permits). These two results seek to extend our understanding of any specific land-use regulation conflict situation and facilitate the decisionmaking process for issuing building permits in our case for the intended users.

\subsection{Inventory of land-use regulations comprising 3D components}

The inventory identifies the land-use regulations that comprise $3 \mathrm{D}$ components and distinguish semantic aspects of regulations. In this part, the most common land-use regulations that need to be checked for issuing a building permit (as a use-case) are reviewed. These regulations are based on "Building Regulations 2018, Authorised Version No. 001, S.R. No. 38/2018" of the Victorian Government ${ }^{2}$ in Australia. Based on the work of Noardo et al. (2020), the following tables show our proposed inventory of land-use regulations. The main characteristics considered in this inventory include having 3D components (e.g. height, depth, and volume of building elements or 3D land-use regulations) and semantic aspects. Semantic aspects will mainly facilitate understanding of potential semantic conflicts for proposed (planned) buildings in a planning permit process. For instance, window of a habitable room in a proposed (planned) building should be distinguishable from the other windows. In order to identify land-use regulations comprising 3D components, more than 100 regulations $(2 \mathrm{D} \&$ $3 \mathrm{D})$ that should be considered in the planning system were reviewed and classified based on their characteristics into four main classes as:

1- Zoning and dimensioning: If the regulation has some rules and criteria, which are the same for its entire zone (i.e. they differ based on the characteristics of their zone), or they are related to dimensions, they will be in this category. Common regulations in this class are as follows:

- Site Coverage: Regulation related to that part of the proposed lot that is covered by buildings. It is often expressed as a percentage of the area of the land or densification level.

- Building Height: The vertical distance between ground level and top of the roof.

- Street Setbacks (Max \& Min): Regulation related to the minimum and maximum distance from the boundary of building to the street.

- Side and Rear Setbacks: It is related to the setback from a side or rear boundary of the building.

- Private Open Space: Regulation related to an unroofed area of land, or a deck, terrace, patio, balcony, pergola, veranda, gazebo, swimming pool, or spa.

- Walls and Carports on Boundaries: Regulation related to a wall or carport of a building constructed on its side or rear boundary.

- Car Parking Spaces: Number of car parking spaces, underground and in covered areas.

Table 1 summarises these regulations by describing their 3D components and semantic aspects.

\begin{tabular}{|l|l|l|}
\hline Reg. Name & 3D Components & Semantic Aspects \\
\hline Site Coverage & $\begin{array}{l}\text { - Different } \\
\text { vertical levels } \\
\text { of buildings }\end{array}$ & $\begin{array}{l}\text { - Information related to swimming } \\
\text { pools or spas, unroofed terraces, } \\
\text { unroofed patios, unroofed decks and } \\
\text { pergolas } \\
\text { - Width of eaves, fascia and gutters }\end{array}$ \\
\hline Building Height & $\begin{array}{l}\text { - Height of } \\
\text { building } \\
\text { elements }\end{array}$ & $\begin{array}{l}\text { - Type of entities (e.g. the height of } \\
\text { ventilation and air conditioning, } \\
\text { entrance storey, etc.) }\end{array}$ \\
\hline $\begin{array}{l}\text { Street Setbacks } \\
\text { (Side and Rear) }\end{array}$ & $\begin{array}{l}\text { - Overhanging } \\
\text { objects like } \\
\text { balconies }\end{array}$ & $\begin{array}{l}\text { - Type of street setbacks (i.e. side or } \\
\text { rear) }\end{array}$ \\
\hline $\begin{array}{l}\text { Side and Rear } \\
\text { Setbacks }\end{array}$ & $\begin{array}{l}\text { - Overhanging } \\
\text { objects like } \\
\text { balconies }\end{array}$ & $\begin{array}{l}\text { - Type of setbacks (i.e. side or rear) } \\
\text { - Type of boundaries }\end{array}$ \\
\hline $\begin{array}{l}\text { Private Open } \\
\text { Space }\end{array}$ & $\begin{array}{l}\text { - Overhanging } \\
\text { objects }\end{array}$ & $\begin{array}{l}\text { - Information related to a deck, } \\
\text { terrace, patio, balcony, pergola, } \\
\text { veranda, gazebo, swimming pool or } \\
\text { spa }\end{array}$ \\
\hline $\begin{array}{l}\text { Walls and } \\
\text { Carports on } \\
\text { Boundaries }\end{array}$ & $\begin{array}{l}\text { - The height of } \\
\text { walls }\end{array}$ & $\begin{array}{l}\text { - Type of walls } \\
\text { - Type of boundaries (e.g. side and } \\
\text { rear) }\end{array}$ \\
\hline $\begin{array}{l}\text { Car Parking } \\
\text { Spaces }\end{array}$ & $\begin{array}{l}\text { - Underground } \\
\text { spaces }\end{array}$ & $\begin{array}{l}\text { - Functionality of car parking spaces } \\
\text { (e.g. bikes, cars). }\end{array}$ \\
\hline
\end{tabular}

Table 1. Zoning and dimensioning regulations

\footnotetext{
${ }^{2}$ http://www.legislation.vic.gov.au
} 
2- Lights and shadows: If the regulation is related to sun or skylight and shadow, it will be in this category. Common regulations in this class are as follows:

- Daylight to Existing Habitable Room Windows: The natural light of the day for existing buildings adjoining proposed (planned) building.

- Solar Access to Existing north-facing Habitable Room Windows: Based on Victorian government definition, "north-facing window means a window of a room that has an axis perpendicular to its surface oriented true north $20^{\circ}$ west to true north $30^{\circ}$ east".

- Overshadowing of Recreational Private Open Space: Recreational private open spaces are generally intended for outdoor recreation activities.

- Daylight to Habitable Room Windows: The natural light of the day for a proposed (planned) building.

Table 2 summarises the aforementioned regulations by describing their 3D component and semantic aspects.

\begin{tabular}{|l|l|l|}
\hline Reg. Name & 3D Components & Semantic Aspects \\
\hline $\begin{array}{l}\text { Daylight to } \\
\text { Existing Habitable } \\
\text { Room Windows }\end{array}$ & $\begin{array}{l}\text { - The height of adjoining } \\
\text { walls }\end{array}$ & - Type of windows \\
\hline $\begin{array}{l}\text { Solar Access to } \\
\text { Existing north- } \\
\text { facing Habitable } \\
\text { Room Windows }\end{array}$ & - Building height & - Type of windows \\
\hline $\begin{array}{l}\text { Overshadowing of } \\
\text { Recreational } \\
\text { Private Open } \\
\text { Space }\end{array}$ & $\begin{array}{l}\text { - Height of proposed } \\
\text { (planned) building } \\
\text { Height of adjoining } \\
\text { buildings }\end{array}$ & - Type of open spaces \\
\hline $\begin{array}{l}\text { Daylight to } \\
\text { Habitable Room } \\
\text { Windows }\end{array}$ & $\begin{array}{l}\text { - Height of building } \\
\text { elements in room's front } \\
\text { outdoor space }\end{array}$ & $\begin{array}{l}\text { - Information related } \\
\text { to veranda, porch, } \\
\text { deck or balcony, and } \\
\text { carports }\end{array}$ \\
\hline
\end{tabular}

Table 2. Lights and shadows regulations

3- Viewshed: It is related to the line of sight.

- Overlooking: A bedroom on a proposed (planned) building must not provide a direct line of sight to adjoining bedrooms in neighbouring buildings.

- Projections beyond Street Alignment: Street alignment means the line between a street and an allotment.

Table 3 summarises these two regulations by describing their $3 \mathrm{D}$ component and semantic aspects.

\begin{tabular}{|l|l|l|}
\hline Reg. Name & 3D Components & Semantic Aspects \\
\hline Overlooking & $\begin{array}{l}\text { - Height of the } \\
\text { window of habitable } \\
\text { room in planned / } \\
\text { existing buildings } \\
\text { - Height of the level of } \\
\text { habitable room }\end{array}$ & $\begin{array}{l}\text { - Type of windows } \\
\text { - Information related to a } \\
\text { balcony, a terrace, a deck or a } \\
\text { patio }\end{array}$ \\
\hline $\begin{array}{l}\text { Type of open spaces } \\
\text { Projections } \\
\text { beyond Street } \\
\text { Alignment }\end{array}$ & $\begin{array}{l}\text { - Overhanging objects } \\
\text { like balconies }\end{array}$ & $\begin{array}{l}\text { Information related to the type } \\
\text { of entities (Balconies, } \\
\text { Verandas, etc.) } \\
\text { Type of streets (i.e. Narrow, } \\
\text { Medium, and Wide) }\end{array}$ \\
\hline
\end{tabular}

Table 3. Viewshed regulations

4- Uncommon regulations: Those regulations that are very specific in a jurisdiction, and do not belong to the previous classes. For example, there is a number of regulations for "Fences" comprising 3D components such as front fence height and fence setbacks from side and rear boundaries.

\subsection{Land-use regulation conflicts}

After exploring different land-use regulations, and in order to enhance the current decision-making process for urban planners in a situation where many land-use regulations are involved, this section presents the possible conflicts that may arise in a building permit process. To this purpose, the conflicts are reviewed by considering two aspects. First, we have traced the land-use regulation conflicts based on the traditional way of examining a spatial data integration process including spatial, semantic, and temporal conflicts (Fileto, 2001; Mohammadi, 2008; Wang and $\mathrm{Hu}, 2009$ ). This classification aims to group land-use regulation conflicts by considering the heterogeneity of the sources of data. Second, the magnitude of land-use regulation conflicts that influences the decision of issuing or rejecting a building permit is investigated.

\subsubsection{Classification of land-use regulation conflicts}

This classification will mainly help the users in a data integration process in order to know several conflicts that may arise by the integration of different datasets in a building permit process. The proposed classification includes three main classes named spatial (geometric and topologic sub-classes), semantic (syntactic, structural or schematic, and sense or meaning subclasses), and temporal conflicts. Table 4 summarises the proposed classification by bringing several examples in a building permit process, and the classes are explained in more detail afterward.

\begin{tabular}{|c|c|c|}
\hline $\begin{array}{l}\text { Type of } \\
\text { Conflict }\end{array}$ & Sub-Class & Examples in the building permit process \\
\hline \multirow[t]{2}{*}{ Spatial } & Geometric & $\begin{array}{l}\text { 1) Having a } 2 \mathrm{D} \text { architectural plan and a } 3 \mathrm{D} \text { city } \\
\text { model } \\
\text { 2) Having BIM data with no information about } \\
\text { the coordinate system }\end{array}$ \\
\hline & Topologic & $\begin{array}{l}\text { Intersection or overlap between two lots } \\
\text { boundaries }\end{array}$ \\
\hline \multirow{3}{*}{ Semantic } & Syntactic & Apartment and Apt \\
\hline & $\begin{array}{l}\text { Structural } \\
\text { or } \\
\text { schematic }\end{array}$ & $\begin{array}{l}\text { The hierarchical level of internal parts of a building } \\
\text { in two datasets may cause conflict when it is a data } \\
\text { value in one relational schema and a relation in } \\
\text { another relational schema. }\end{array}$ \\
\hline & $\begin{array}{l}\text { Sense or } \\
\text { meaning }\end{array}$ & $\begin{array}{l}\text { 1) Floor and Storey } \\
\text { 2) Habitable room and Bedroom }\end{array}$ \\
\hline \multirow[b]{2}{*}{ Temporal } & Date & $\begin{array}{l}\text { If two BIMs in the same neighborhood at the same } \\
\text { time request a building permit, temporal conflicts } \\
\text { may arise. }\end{array}$ \\
\hline & Duration & $\begin{array}{l}\text { Some regulations depend on the existing buildings } \\
\text { and density of a zone. For example, after reaching } \\
\text { a specific number of buildings, the changes over } \\
\text { the time in regulations are predictable. }\end{array}$ \\
\hline
\end{tabular}

Table 4. Classification of possible conflicts by integrating different sources of information

- Spatial Conflicts: In the data integration process, the first important part that describes the geometric and topological inconsistencies is considered as spatial conflicts.

○ Geometric: For spatial conflicts with a geometric aspect, first, position and coordinate systems and second, shape (linked to the dimension of the point $0 \mathrm{D}$, line $1 \mathrm{D}$, surface $2 \mathrm{D}$ or polyhedron $3 \mathrm{D}$ primitives), size (scale factor), and orientation of the entities should be taken into account.

- Topologic: It considers the conflicts that arise based on the interior, boundary, and exterior parts of the objects. Having polygons with non-planar surfaces or having intersection between edges or polygons are some examples of topological conflicts. It should be 
noted that when there is only one dataset, these conflicts could be equivalent to design conflicts.

- Semantic Conflicts: Semantic conflicts correspond to disagreement over the meaning, understanding, or intended use of the same or similar information (Fileto, 2001). Generally, these conflicts can be discussed in three levels, including:

- Syntax level: It is related to conflicts in terms of characters (strings).

- Structure or schema level: It considers whether the same term in one dataset is located at the same level in the data model (or schema) of another dataset.

- Sense or meaning level: It consists of the conflicts that may occur between meanings of the terms.

- Temporal Conflicts: Temporal conflicts are notable in two terms of "date" and "duration". Temporal conflicts can greatly affect the building permit process. As an example of conflicts related to date, consider two highrises in the same neighbourhood applying for the building permits. In this case, based on the date of application, the second one should not restrict rights associated with the first one. For example, the second submitted application cannot restrict solar access to the first submitted application.

\subsubsection{Magnitude of land-use regulation conflicts}

As mentioned before, to support our hypothesis, we now propose a way of ranking the conflicts between the proposed planned building with physical objects and land-use regulations. We do believe that this classification will improve the decisionmaking process in issuing a building permit, more specifically in the integration of spatio-semantic data. Similar to clash classification in BIM (i.e. hard and soft clashes), two conflict's magnitudes for land-use regulations are proposed (i.e. hard and soft conflicts). In the proposed classification, unlike BIM clashes in which the main entities are building elements, the main entities are land-use regulations. Soft conflicts can be recognized or resolved with a limited number of data analysis by the decision-makers. While hard conflicts include situations that are more complex, for which decision-makers require a higher level of data analysis and knowledge. In the following, first, the proposed variables for evaluating the amount of data analysis are indicated and then, they are explained by three concrete examples.

1) The number of land-use regulations involved in the conflicts.

- $\quad$ Soft $=1$

- Hard $\geq 2$

2) The number of physical (building) objects involved in the conflicts.

- $\quad$ Soft $<2$

- Hard $\geq 2$

3) The level of detail ${ }^{3}$ of the planned building (LoD "P").

- $\quad$ Soft $=$ CityGML LoD 1 (or equivalent in BIM modelling)

- Hard = CityGML LoD 2 \& LoD 3 (or equivalent in BIM modelling)

4) The level of detail of surrounding buildings (LoD "S").

- $\quad$ Soft $=$ CityGML LoD 1

\footnotetext{
${ }^{3}$ Level of Detail (LoD) refers to the degree of detail used to model the city objects (planned building or existing buildings). For this version and as a first appraisal, we assume the 3D city model is based on CityGML but in fact, it could be any 3D modelling design.
}

- Hard = CityGML LoD $2 \&$ LoD 3

5) The 3D spatial configuration of the land-use regulations causing the conflict: It refers to the shapes utilised to model the land-use regulations.

- $\quad$ Soft $=$ regular solid

- Hard = irregular 3D shapes (could be line, surface, or solid)

Finally, based on the proposed variables, the number of soft and hard conflicts is counted, and the conflict belongs to the class that is outnumbered.

For instance, as is shown in Figure 3, the highest object of the proposed (planned) building must not exceed the maximum allowed height regulation. If it does, in this case, the conflict consists of one regulation (i.e. building height regulation) and mostly one building object (i.e. the roof of the proposed (planned) building). In addition, for identifying the conflict, since the roof shape of the proposed (planned) building is required, at least LoD 2 is needed, and adjoining existing buildings are not required. Finally, a regular solid (i.e. cuboid) can model the height regulation. Therefore, according to proposed variables, the magnitude of this conflict is "Soft" as is summarised in table 5 .

\begin{tabular}{|c|c|c|c|c|c|c|}
\hline $\begin{array}{l}\text { Planned } \\
\text { building }\end{array}$ & $\begin{array}{l}\text { No. of } \\
\text { regulations }\end{array}$ & $\begin{array}{c}\text { No. of } \\
\text { building } \\
\text { objects }\end{array}$ & $\begin{array}{l}\text { LoD } \\
\text { "P" }\end{array}$ & $\begin{array}{l}\text { LoD } \\
\text { "S" }\end{array}$ & $\begin{array}{c}\text { Spatial } \\
\text { configuration } \\
\text { of regulation }\end{array}$ & $\begin{array}{l}\text { Class of } \\
\text { conflict }\end{array}$ \\
\hline Value & 1 & 1 & 2 & $\begin{array}{c}\text { Not } \\
\text { required }\end{array}$ & Regular Solid & \multirow{2}{*}{$\begin{array}{c}\text { Soft } \\
\text { Conflict }\end{array}$} \\
\hline $\begin{array}{l}\text { Magnitude } \\
\text { of conflict }\end{array}$ & Soft & Soft & Hard & - & Soft & \\
\hline
\end{tabular}

Table 5. Classification of the magnitude of building height regulation conflict

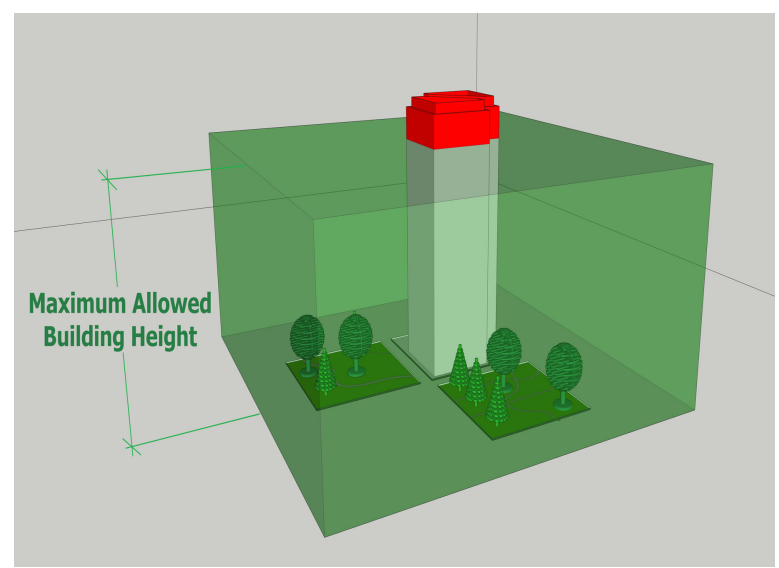

Figure 3. Building height regulation conflict (in RED colour)

On the other hand, if the proposed (planned) building respects the height regulation, it may restrict the solar access of the other buildings or cause a shadow in its adjoining building as is illustrated in Figure 4. In this scenario, the conflict consists of two regulations (i.e. building height and overshadowing regulations) and two building objects (i.e. the roof of the planned building and private open space of existing buildings). In addition, for identifying the conflict, since the roof shape of the proposed (planned) building and the private open space of existing adjoining buildings are needed, at least LoD 2 is required for the proposed (planned) building, and for the existing buildings, LoD 3 is needed. Finally, a regular solid cannot model shadow regulation. Therefore, according to proposed variables, the magnitude of this conflict is "Hard" as is summarised in table 6 . 


\begin{tabular}{|c|c|c|c|c|c|c|}
\hline $\begin{array}{c}\text { Planned } \\
\text { building }\end{array}$ & $\begin{array}{c}\text { No. of } \\
\text { regulations }\end{array}$ & $\begin{array}{c}\text { No. of } \\
\text { building } \\
\text { objects }\end{array}$ & $\begin{array}{c}\text { LoD } \\
\text { "P" }\end{array}$ & $\begin{array}{c}\text { LoD } \\
\text { "S" }\end{array}$ & $\begin{array}{c}\text { Spatial } \\
\text { configuration of } \\
\text { regulation }\end{array}$ & $\begin{array}{c}\text { Class of } \\
\text { conflict }\end{array}$ \\
\hline Value & 2 & 2 & 2 & 3 & irregular shape & Hard \\
\cline { 1 - 5 } $\begin{array}{c}\text { Magnitude } \\
\text { of conflict }\end{array}$ & Hard & Hard & Hard & Hard & Hard & Conflict \\
\hline
\end{tabular}

Table 6. Classification of the magnitude of building height and overshadowing regulations conflict

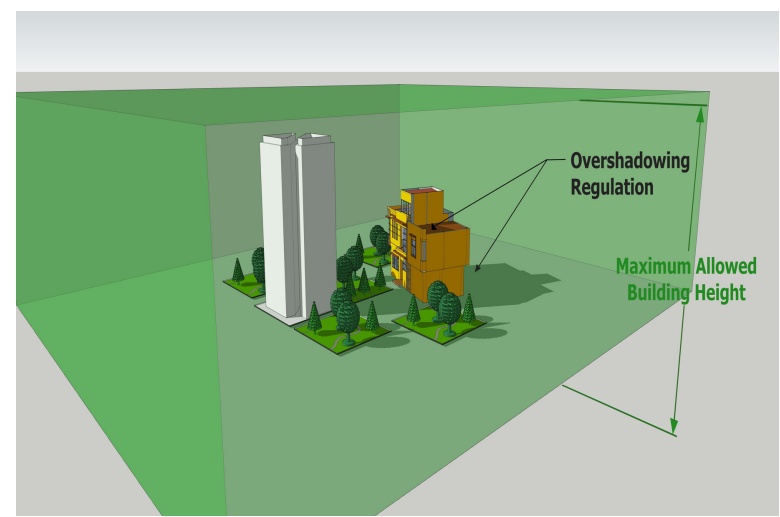

Figure 4. Hard conflict between building height and overshadowing regulations (the grey is the planned building (left) and the other is the existing building (right))

As another example, as is shown in Figure 5, for checking overlooking regulation, the window of a habitable room of the proposed (planned) building must not provide a direct line of sight to the windows of a habitable room in existing buildings. If it does, in this case, the conflict consists of one regulation (i.e. overlooking regulation) and two building objects (i.e. the window of a habitable room in the proposed (planned) building and the window of a habitable room in the existing adjoining building). In addition, for identifying the conflict, since the windows should be modelled, the LoD 3 is needed for both proposed (planned) and existing buildings. Finally, a regular solid (i.e. triangular prism) can model the overlooking regulation. Therefore, according to proposed variables, the magnitude of this conflict is "Hard" as is summarised in table 7.

\begin{tabular}{|c|c|c|c|c|c|c|}
\hline $\begin{array}{c}\text { Planned } \\
\text { building }\end{array}$ & $\begin{array}{c}\text { No. of } \\
\text { regulations }\end{array}$ & $\begin{array}{c}\text { No. of } \\
\text { building } \\
\text { objects }\end{array}$ & $\begin{array}{c}\text { LoD } \\
\text { "P" }\end{array}$ & $\begin{array}{c}\text { LoD } \\
\text { "S" }\end{array}$ & $\begin{array}{c}\text { Spatial } \\
\text { configuration of } \\
\text { regulation }\end{array}$ & $\begin{array}{c}\text { Class of } \\
\text { conflict }\end{array}$ \\
\hline Value & 1 & 2 & 3 & 3 & Regular Solid & Hard \\
Conflict \\
$\begin{array}{c}\text { Magnitude } \\
\text { of conflict }\end{array}$ & Soft & Hard & Hard & Hard & Soft & Cof \\
\hline
\end{tabular}

Table 7. Classification of the magnitude of overlooking regulation conflict

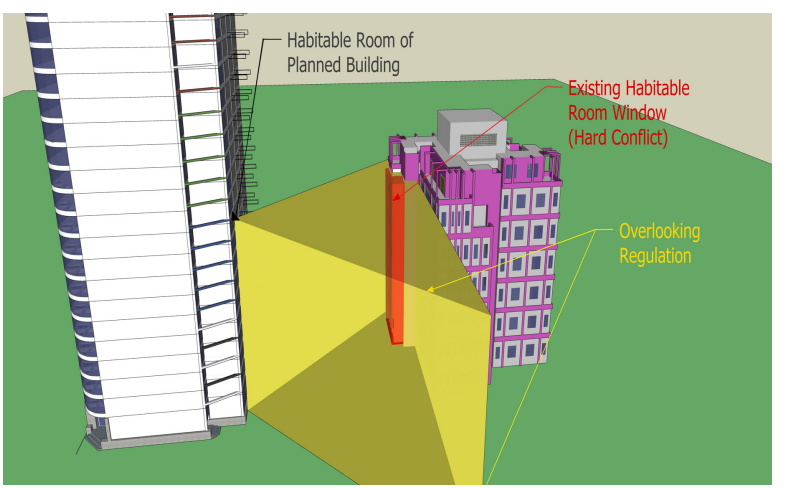

Figure 5. Overlooking regulation conflict (in RED colour)
Obviously, after having ranked the conflicts between the planned building and the land-use regulations, the data processing does not stop there; we afterward have to fix the conflict. As indicated, this paper presents the progress of an ongoing research project, and one of the next steps is exactly to provide analytical tools to meet this need.

\section{CONCLUSION AND FUTURE STEPS}

This paper firstly explored the land-use regulations and then, the possible conflicts that may arise in the issuance of a building permit. The inventory of land-use regulations demonstrated that many land-use regulations contain 3D components (e.g. building height, solar access, daylight, and shadowing), which make the decision-making process a challenging task with traditional 2D systems. Accordingly, after exploring land-use regulations, two classifications to identify and evaluate the conflicts are proposed from two points of view (i.e. data sources, and magnitude of conflicts). Since the building permit process is a common process in different territories, the results can be applied to other jurisdictions with some minor changes. The main value of these classifications are to extend our understanding of 3D land-use regulation and to support decision-makers in the detection of spatio-semantic conflicts between the planned building, the existing buildings, and the land-use regulations. We also believe that they will contribute to model and visualize land-use regulations as part of the $3 \mathrm{D}$ city modelling (CityGML and BIM). The classification system for the magnitude of the conflicts is not yet fully validated, neither confronted with a concrete decision-making process, and this is part of the upcoming work. For example, the aggregation of the variables needs to be validated with users. We are currently working on the design of a use-case to detect spatio-semantic conflicts inspired by issuing building permits and its implementation with $3 \mathrm{D}$ city models for the city of Melbourne.

\section{ACKNOWLEDGEMENTS}

This project is funded by NSERC RGPIN-2015-05514 (JPouliot). The authors would like to thank Ordnance Survey GB (https://www.ordnancesurvey.co.uk) and 1Spatial (https://1spatial.com/) for sponsoring the publication of this paper.

\section{REFERENCES}

Akinci, B., Fischen, M., Levitt, R., Carlson, R., 2002. Formalization and automation of time-space conflict analysis. J. Comput. Civ. Eng. 16, 124-134.

Arnold, C.A., 2006. The structure of the land use regulatory system in the United States. J. L. Use Envtl. L. 22, 441.

Benner, J., Geiger, A., Häfele, K.-H., 2010. Concept for building licensing based on standardized 3D geo information, in: Proceedings of the 5th International 3D GeoInfo Conference, Berlin, Germany. pp. 3-4.

Biljecki, F., Stoter, J., Ledoux, H., Zlatanova, S., Cöltekin, A., 2015. Applications of 3D city models: State of the art review. ISPRS Int. J. Geo-Information 4, 2842-2889.

Cann, D.M., 2018. The structure of municipal political ideology. State Local Gov. Rev. 50, 37-45. 
Döllner, J., Baumann, K., Buchholz, H., 2006a. Virtual 3D city models as foundation of complex urban information spaces, in: Proceedings of the 11th International Conference on Urban Planning and Spatial Development in the Information Society, Vienna, Austria, 13-16 February 2006.

Döllner, J., Kolbe, T.H., Liecke, F., Sgouros, T., Teichmann, K., 2006b. The virtual 3d city model of berlin-managing, integrating, and communicating complex urban information, in: Proceedings of the 25th International Symposium on Urban Data Management UDMS 2006 in Aalborg, Denmark, 15-17 May 2006

Durham Jr, W.C., Scharffs, B.G., 2019. Law and religion: National, international, and comparative perspectives. Wolters Kluwer Law \& Business.

Eastman, C., Teicholz, P., Sacks, R., Liston, K., Handbook, B.I.M., 2008. A guide to building information modeling for owners, managers, designers, engineers and contractors.

Fileto, R., 2001. Issues on interoperability and integration of heterogeneous geographical data, in: Proceedings of the Third Brazilian Symposium on Geoinformatics.

Forester, J., 1987. Planning in the face of conflict: Negotiation and mediation strategies in local land use regulation. J. Am. Plan. Assoc. 53, 303-314.

Gresch, P., Smith, B., 1985. Managing spatial conflict: the planning system in Switzerland. Prog. Plann. 23, 155-251.

Grimmer, N.G., 2007. Opps-It Turns out You Shouldn't Have Built That There: Erroneously Issued Building Permits in Texas. Hous. L. Rev. 44, 1415.

Kochan, D.J., 2014. A framework for understanding property regulation and land use control from a dynamic perspective. Mich. J. Envtl. Admin. L. 4, 303.

Kolbe, T.H., 2009. Representing and exchanging 3D city models with CityGML, in: 3D Geo-Information Sciences. Springer, pp. 15-31.

Ledoux, H., 2018. val3dity: validation of 3D GIS primitives according to the international standards. Open Geospatial Data, Softw. Stand. 3, 1 .

Matejka, P., Sabart, D., 2018. Categorization of clashes and their impacts on construction projects, in: International Scientific Conference Engineering for Rural Development, 23rd to 25th May, Jelgava, Available at: Www. Tf. Llu. Lv/Conference/Proceedings2018/Papers N.

Mayer, C.J., Somerville, C.T., 2000. Land use regulation and new construction. Reg. Sci. Urban Econ. 30, 639-662.

Mehrbod, S., Staub-French, S., Mahyar, N., Tory, M., 2019. Beyond the clash: investigating BIM-based building design coordination issue representation and resolution. ITcon 24, 3357.

Mohammadi, H., 2008. The Integration of multi-source spatial datasets in the context of SDI Initiatives. Citeseer.

Neuville, R., Pouliot, J., Poux, F., De Rudder, L., Billen, R., 2018. A formalized 3D geovisualization illustrated to selectivity purpose of virtual 3D city model. ISPRS Int. J. Geo-Information 7, 194.

Noardo, F., Arroyo Ohori, K., Biljecki, F., Krijnen, T., Ellul, C., Harrie, L., Stoter, J., 2019. Geobim benchmark 2019: Design and initial results. Int. Arch. Photogramm. Remote Sens. Spat. Inf. Sci. - ISPRS Arch. 42, 1339-1346. https://doi.org/10.5194/isprs-archives-XLII-2-W13-1339-2019

Noardo, F., Ellul, C., Harrie, L., Overland, I., Shariat, M., Arroyo Ohori, K., Stoter, J., 2020. Opportunities and challenges for GeoBIM in Europe: developing a building permits use-case to raise awareness and examine technical interoperability challenges. J. Spat. Sci. 65, 209-233. https://doi.org/10.1080/14498596.2019.1627253

Olsson, P.-O., Axelsson, J., Hooper, M., Harrie, L., 2018. Automation of building permission by integration of BIM and geospatial data. ISPRS Int. J. Geo-Information 7, 307.

Reddy, K.P., 2011. BIM for building owners and developers: making a business case for using BIM on projects. John Wiley $\&$ Sons.

Salsich, P.W., Tryniecki, T.J., 1998. Land use regulation: A legal analysis \& practical application of land use law. Real Property Probate and Trust Law American Bar Association.

Sampaio, A.Z., Berdeja, E., 2017. Collaborative BIM environment as a support to conflict analysis in building design, in: 2017 4th Experiment@ International Conference (Exp. at'17). IEEE, pp. 77-82.

Selmi, D.P., Kushner, J.A., Ziegler, E.H., DiMento, J.F.C., Echeverria, J., 2017. Land use regulation: cases and materials. Wolters Kluwer Law \& Business.

Shojaei, D., Olfat, H., Faundez, S.I.Q., Kalantari, M., Rajabifard, A., Briffa, M., 2017. Geometrical data validation in 3D digital cadastre - A case study for Victoria, Australia. Land use policy $68,638-648$.

Stadler, A., Kolbe, T.H., 2007. Spatio-semantic coherence in the integration of $3 \mathrm{D}$ city models, in: Proceedings of the 5 th International ISPRS Symposium on Spatial Data Quality ISSDQ 2007 in Enschede, The Netherlands, 13-15 June 2007.

Van Berlo, L., Dijkmans, T., Stoter, J.E., 2013. Experiment for inegrating Dutch 3D spatial planning and BIM for checking building permits, in: 8th 3DGeoInfo Conference \& WG II/2 Workshop, Istanbul, Turkey, 27-29 November 2013, ISPRS Archives Volume II-2/W1. ISPRS.

Wang, Y., Hu, S., 2009. Spatial Data Integration and Conflicts Resolving Approaches, in: 2009 International Conference on Information Management, Innovation Management and Industrial Engineering. IEEE, pp. 355-358.

Webster, N., 1971. Webster's Third New International Dictionary of the English Language, Unabridged: A MerriamWebster. Editor in Chief: Philip Babcock Gove and the Merriam-Webster Editorial Staff. G. \& C. Merriam Company.

Wu, I., Chiu, Y., 2010. 4D Workspace conflict detection and analysis system, in: Proceedings of the 10th International Conference on Construction Applications of Virtual Reality. 